\title{
Zastosowanie mometazonu oraz lewocetyryzyny i desloratadyny w leczeniu chorób alergicznych
}

The use of mometasone and levocetirizine, desloratadine in the treatment of allergic diseases

\author{
Bolesław Samoliński ${ }^{1,2}$, Oksana Wojas ${ }^{1,2}$, Edyta Krzych-Fałta1, 3
} ${ }^{1}$ Zakład Alergologii i Immunologii Klinicznej, Uniwersyteckie Centrum Kliniczne, Warszawski Uniwersytet Medyczny Kierownik Zakładu: prof. dr hab. n. med. Bolesław Samoliński ${ }^{2}$ Zakład Profilaktyki Zagrożeń Środowiskowych, Alergologii i Immunologii Klinicznej, Warszawski Uniwersytet Medyczny

Kierownik Zakładu: prof. dr hab. n. med. Bolesław Samoliński ${ }^{3}$ Zakład Podstaw Pielęgniarstwa, Warszawski Uniwersytet Medyczny Kierownik Zakładu: dr hab. n. o zdr. Edyta Krzych-Fałta

\begin{abstract}
Streszczenie:
Terapia chorób alergicznych odgrywa krytyczną rolę w dobrej kontroli choroby. Podstawową grupą leków stosowanych w alergicznym nieżycie nosa są glikokortykosteroidy donosowe, w tym mometazon, który skutecznie hamuje proces zapalny, zmniejsza obrzęk i podrażnienie. Z kolei leki przeciwhistaminowe II generacji, w tym lewocetyryzyna i desloratadyna, są jednymi z najpopularniejszych i najlepiej przebadanych leków stosowanych w chorobach alergicznych. Wspólną cechą wszystkich wymienionych leków jest wysoki profil bezpieczeństwa, który kwalifikuje te grupy jako niezawodne, ale również skuteczne.
\end{abstract}

\section{Abstract:}

The therapy of allergic diseases plays a critical role in the good control of the disease. The main group of drugs used in allergic rhinitis are intranasal glucocorticosteroids including mometasone, which effectively inhibits the inflammatory process, reduces swelling and irritation. On the other hand, second-generation antihistamines including levocetirizine and desloratadine are among the most popular and the most studied drugs used in allergic diseases. What they all have in common is their high safety profile, which makes these groups of drugs not only reliable but also effective.

Słowa kluczowe: alergiczny nieżyt nosa, glikokortykosteroidy, leki przeciwhistaminowe II generacji

Key words: allergic rhinitis, glucocorticosteroids, second-generation antihistamines

Wstęp

Choroby alergiczne, ze względu na duże rozpowszechnienie, stanowią poważny problem współczesnej medycyny i zdrowia publicznego. W literaturze przedmiotu określa się je mianem chorób cywilizacyjnych i wielopokoleniowych. Szacuje się, że prawie $40 \%$ ogółu polskiej populacji ma alergię, w tym na 
alergiczny nieżyt nosa (ANN) cierpi $25 \%$, astmę rozpoznaje się u 5\% ogółu badanych, objawy astmy manifestuje $12 \%$, atopowe zapalenie skóry $9 \%$, pokrzywkę ma $2,1-6,7 \%$ populacji dziecięcej, a alergię pokarmową $13 \%$ badanych $[1,2]$. Jak wynika z badań, najczęściej w opisanej grupie chorób rozpoznaje się ANN, który jest definiowany jako „klinicznie jawna choroba nosa, powstająca po ekspozycji na alergen $\mathrm{w}$ wyniku zależnego od przeciwciał IgE zapalenia błony śluzowej tego narządu" [1,3]. Ze względu na wspólne powinowactwo atopii $\mathrm{w}$ przebiegu reakcji IgE-zależnej współwystępuje on z innymi chorobami alergicznymi: $73,6 \%$ osób z rozpoznaną astmą deklaruje występowanie nieżytów nosa, a spośród osób obserwujących u siebie świsty oskrzelowe nieżyt nosa deklaruje $62,2 \%$. Ponadto $\mathrm{w}$ populacji osób $\mathrm{z}$ nieżytem nosa rozpoznaje się astmę u prawie $9,4 \%$, a świsty deklaruje $23,2 \%$. U pacjentów z symptomami alergicznego nieżytu nosa atopowe zapalenie skóry rozpoznaje się u $1,6 \%$, natomiast u osób $\mathrm{z}$ rozpoznanym atopowym zapaleniem skóry w $34,12 \%$ występują również objawy ANN [1, 4, 5].

Należy nadmienić, że alergiczny nieżyt nosa znamiennie istotnie pogarsza jakość życia na wszystkich płaszczyznach, w sferach osobniczej i społecznej. W związku z powyższym wydaje się zasadne wdrażanie działań na rzecz prewencji wtórnej z tzw. złożonym mechanizmem dobrej kontroli choroby. Rekomendacje zespołu polskich badaczy w dokumencie PoSLeNN (Polskie Standardy Leczenia Nieżytów Nosa) zwracają szczególną uwagę na potrzebę wdrażania skutecznej terapii nieżytów nosa, tak aby w konsekwencji minimalizować odległe skutki zdrowotne, w tym astmę. Zaleca się, aby u chorych na ANN stosować: doustne leki przeciwhistaminowe nowej generacji, które nie powodują sedacji, glikokortykosteroidy donosowe (dnGKS) u dorosłych i dzieci, a w przypadku leczenia zarówno sezonowego, jak i całorocznego alergicznego nieżytu nosa jest rekomendowane stosowanie glikokortykosteroidów (GKS) zamiast leków przeciwhistaminowych II generacji. Co istotne, w przypadku nasilających się dolegliwości o charakterze umiarkowanym/ ciężkim i przewlekłym podstawą leczenia powinny być miejscowo działające GKS [4]. Powyższe stanowisko jest zgodne z wytycznymi raportu ARIA (Allergic Rhinitis and its Impact on Asthma), które jednocześnie wskazuje na potrzebe kontroli efektywności terapii w okresie $2-4$ tygodni po zastosowanym leczeniu, aby w sytuacji braku poprawy klinicznej dokonać modyfikacji terapii (intensyfikacja leczenia, ocena współpracy pacjenta i rewizja rozpoznania choroby) [3].

\section{Leczenie pierwszego rzutu alergicznego nieżytu nosa}

Wspólnym celem terapii chorób alergicznych, w tym ANN, jest uzyskanie dobrej kontroli choroby. W leczeniu alergicznego nieżytu nosa zaleca się stosowanie dnGKS. Zazwyczaj ich działanie obserwuje się po upływie 7-12 h, a widoczny efekt terapeutyczny uzyskuje się po kilku dniach. Leki te cechują się wysokim stopniem bezpieczeństwa ze względu na niską biodostępność i nie wpływają na oś podwzgórzeprzysadka-nadnercza. Te dostępne na rynku skutecznie redukują symptomy nosowe i istotnie wpływają na lepszą jakość życia, a mometazon (tab. 1) dodatkowo istotnie redukuje objawy oczne w grupie pacjentów $\mathrm{z}$ rozpoznanym ANN [4].

\section{Opisy przypadków}

\section{Przypadek 1.}

30-letnia kobieta zgłosiła się do poradni alergologicznej z powodu utrzymujących się od 5 lat symptomów pod postacią blokady nosa, kataru w godzinach rannych oraz kichania podczas odkurzania. Nie występowały kaszel ani duszność. Objawy miały charakter całoroczny z nasileniem w okresie grzewczym. W wykonanych 6 miesięcy wcześniej punktowych testach skórnych stwierdzono uczulenie na roztocze kurzu domowego. Pacjentka zastosowała profilaktykę przeciwroztoczową oraz przyjmowała nieregularnie doustne leki przeciwhistaminowe. Jednak takie postępowanie nie kontrolowało w pełni symptomów choroby. W poradni alergologicznej wykonano badanie sIgE panel wziewny i otrzymano dodatnie wyniki na alergeny roztoczy - klasa IV Dermatophagoides pteronyssinus i klasa III Dermatophagoides farinae. Rozpoznano przewlekły ANN w stopniu umiarkowanym w przebiegu uczulenia na roztocze kurzu domowego. Zastosowano, zgodnie z zaleceniami dokumentu ARIA, leczenie donosowym preparatem mometazonu w dawce 2 razy dziennie po 2 dawki do każdego otworu nosowego, po czym uzyskano znaczną redukcję symptomów nieżytu nosa. Miejscowe GKS są podstawową i niezawodną grupą leków w terapii alergicznego nieżytu nosa ze względu na silne działanie przeciwzapalne i niewielkie działania niepożądane. Do rozważenia, również u opisywanej chorej, jest wdrożenie immunoterapii swoistej - jako jedynej przyczynowej metody leczenia alergii.

\section{Komentarz}

Biodostępność leku (w zakresie tkanki efektorowej) w obrębie błony śluzowej jamy nosa zwiększa skuteczność i bezpieczeństwo stosowania. Co więcej, 
duże powinowactwo do miejscowego receptora powoduje działanie przeciwzapalne, a część, która przedostaje się do przewodu pokarmowego, jeszcze przed przeniknięciem do układu krążenia ulega biotransformacji w wątrobie. W grupie GKS mometazon wykazuje najwyższy stopień skuteczności i bezpieczeństwa [4]. Mimo odczuwanych dolegliwości (w grupie pacjentów $\mathrm{z}$ rozpoznanym ANN) o charakterze lokalnym nie obserwuje się zmian atroficznych ani cech uszkodzenia nabłonka $[4,6]$. Sam mechanizm działania opiera się na zjawisku łączenia cząstki leku z receptorem w cytoplazmie komórek, który transportowany do jądra komórkowego łączy się następnie z sekwencją echa gradientowego (GRE, gradient recalled echo). Wpływ molekularny na ekspresję genów jest regulowany w bezpośredniej aktywacji transkrypcji genu, represji transkrypcji genu, indukcji transkrypcji genu, indukcji transkrypcji inhibitorów czynników transkrypcyjnych i w destabilizacji mRNA. Ponadto GKS hamują ekspresję genów dla wielu cytokin prozapalnych [4]. Właściwości farmakodynamiczne mometazonu dotyczą: hamowania uwalniania mediatorów reakcji IgE-zależnej, leukotrienów z leukocytów, syntezy i uwalniania IL-1, IL-5, IL-6 oraz czynnika martwicy nowotworów
(TNF- $\alpha$, tumor necrosis factor $\alpha$ ). Dodatkowo jest on silnym inhibitorem wytwarzania leukocytów, a także cytokin Th2, IL-4 i IL-5 [7].

Z kolei właściwości farmakokinetyczne mometazonu ze względu na miejsce stosowania są kolejnym dowodem na wysoki profil bezpieczeństwa: niewielka ilość leku, która przedostaje się do przewodu pokarmowego, ulega metabolizmowi w wątrobie, a metabolity są wydalane z moczem i żółcią [6]. Sama depozycja leku, średnio na poziomie $86 \%$ w jamie nosa, sprawia, że jest on skuteczny miejscowo [15]. Mometazon jest nie tylko wysoce skuteczny w terapii ANN, ale również zastosowany profilaktycznie, kilka tygodni przed sezonem pylenia, zapobiega wystąpieniu objawów okresowego ANN, a przyjmowany z antybiotykiem w zapaleniu zatok przynosowych minimalizuje ryzyko nawrotów [16]. W zestawieniu z innymi lekami w tzw. kombinacji head to head mometazon wykazuje wyraźną przewagę [16]. Wykazano skuteczność mometazonu także w terapii skojarzonej z azelastyną. Leczenie to wykazało znamiennie istotną redukcję dolegliwości nosowych vs placebo [17].

Drugą grupą leków istotną w terapii chorób alergicznych, w tym alergicznego nieżytu nosa, są leki

Tabela 1. Leki stosowane w alergicznym nieżycie nosa (na podstawie [8-14]).

\begin{tabular}{|c|c|c|}
\hline Wskazania & Dawkowanie & Działania niepożądane \\
\hline \multicolumn{3}{|r|}{ Mometazon } \\
\hline $\begin{array}{l}\text { - leczenie objawów } \\
\text { sezonowego alergicz- } \\
\text { nego zapalenia błony } \\
\text { śluzowej nosa lub } \\
\text { całorocznego zapa- } \\
\text { lenia błony śluzowej } \\
\text { nosa } \\
\text { - leczenie polipów nosa }\end{array}$ & 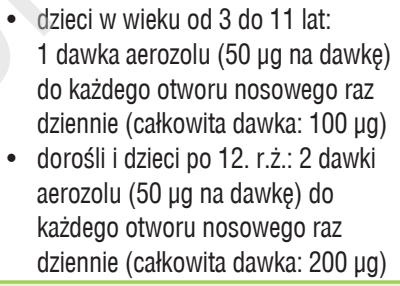 & $\begin{array}{l}\text { - rwadka obsenie z nosa, które zazwyczaj ustępuje samoistnie } \\
\text { głowy. Należy zachować szczególną ostrożność w grupie kobiet w ciąży i karmią- } \\
\text { cych piersią. Ponadto nie zaleca się stosowania mometazonu u osób, u których } \\
\text { diagnozuje się nadwrażliwość na substancję czynną, z opryszczką oraz u pacjentów } \\
\text { po zabiegach chirurgicznych w obrębie nosa. Należy zachować szczególne środki } \\
\text { ostrożności przy immunosupresji, czynnej gruźlicy, nieleczonych zakażeniach } \\
\text { grzybiczych, bakteryjnych, a także ogólnoustrojowych zakażeniach wirusowych }\end{array}$ \\
\hline \multicolumn{3}{|r|}{ Desloratadyna } \\
\hline $\begin{array}{l}\text { - leczenie łagodzące } \\
\text { alergicznego nieżytu } \\
\text { nosa } \\
\text { - } \text { pokrzywka }\end{array}$ & $\begin{array}{l}\text { dzieci w wieku: } \\
\text { - 1-5 lat 1,25 mg (2,5 ml) raz } \\
\text { dziennie } \\
\text { - 6-11 lat 2,5 mg (5 ml) raz dzien- } \\
\text { nie } \\
\text { - po 12. r.ż. i dorośli } 5 \mathrm{mg}(1 \mathrm{tabl} \text {. } \\
\text { lub } 10 \mathrm{ml} \text { syropu) raz dziennie }\end{array}$ & 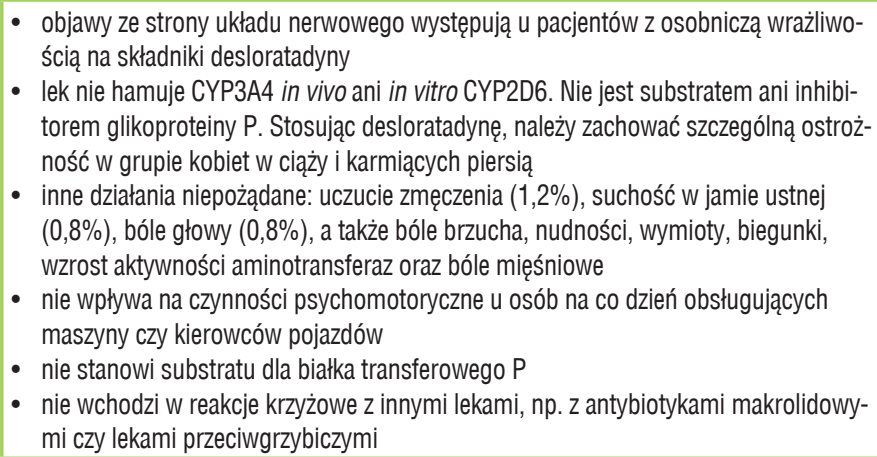 \\
\hline \multicolumn{3}{|r|}{ Lewocetyryzyna } \\
\hline $\begin{array}{l}\text { - leczenie objawowe } \\
\text { alergicznego nieżytu } \\
\text { nosa o charakterze } \\
\text { okresowym i całorocz- } \\
\text { nym } \\
\text { - pokrzywka }\end{array}$ & $\begin{array}{l}\text { - dzieci w wieku: } \\
\text { - 2-6 lat 2,5 mg/24 h } \\
\text {-6-12 lat } 5 \mathrm{mg} / 24 \mathrm{~h} \\
\text { - po 12. r.ż. i dorośli } 5 \mathrm{mg} / 24 \mathrm{~h}\end{array}$ & $\begin{array}{l}\text { - bóle głowy (2,6\%), senność (5,2\%), suchość w jamie ustnej (2,6\%), uczucie } \\
\text { zmęczenia (2,5\%) tożsame vs placebo. Szczególną ostrożność należy zachować } \\
\text { w grupie kobiet w ciąży, karmiących i u osób z zaburzeniami czynności nerek } \\
\text { - } \quad \text { w grupie kierowców i osób obsługujących maszyny lek wywołuje sporadycznie } \\
\text { uczucie senności, zmęczenia i astenii } \\
\text { - } \text { nie stwierdza się niepożądanych interakcji z pseudoefedryną, cymetydyną, ketoko- } \\
\text { nazolem, erytromycyną, azytromycyną, glipizydem i diazepamem }\end{array}$ \\
\hline
\end{tabular}


przeciwhistaminowe II generacji. Dodatkowo - ze względu na patomechanizm, w którym kluczową rolę odgrywa histamina - mają one zastosowanie również w ostrej pokrzywce (o etiologii idiopatycznej). Przykładem skuteczności leków przeciwhistaminowych II generacji są desloratadyna i lewocetyryzyna (tab. 1). Ta pierwsza stosowana przez $7 \mathrm{dni}$ istotnie redukuje średnicę bąbla w grupie chorych z rozpoznaną kontaktową pokrzywką fizykalną. Leki przeciwhistaminowe II generacji są lekami pierwszego wyboru w terapii pokrzywki przewlekłej. Jednak nie zawsze są w pełni skuteczne w leczeniu tej choroby w dawkach standardowych. Eksperci wytycznych europejskich w terapii pokrzywki przewlekłej proponują stosowanie nawet czterokrotnie większych dawek tych leków. Wykazano, iż przyjmowanie zarówno lewocetyryzyny, jak i desloratadyny w terapii pokrzywki przewlekłej opornej na leczenie, w dawkach czterokrotnie większych od zalecanych, cechuje się nie tylko dużą skutecznością w redukcji objawów, lecz także wysokim stopniem bezpieczeństwa [18]. Podobnie dobry efekt terapeutyczny leków przeciwhistaminowych II generacji obserwowano w grupie badanych z przewlekłą pokrzywką spontaniczną, wśród których stosowane duże dawki redukowały odczuwane dolegliwości u 45-65\% ogółu badanych [19].

Skuteczność tej grupy leków jest bezdyskusyjna: są one najlepiej przebadane (ich efektywność została dobrze udokumentowana w randomizowanych, kontrolowanych placebo, wysokiej jakości badaniach klinicznych za pomocą standaryzowanych narzędzi oceny subiektywnej: Total Nasal Score, Visual Analogue Scale, i technik obiektywnych, w tym: rynomanometrii aktywnej przedniej, termografii wizyjnej czy komory alergenowej powszechnie znanej jako Vienna Chamber) i najczęściej stosowane w wybranych chorobach o podłożu IgE-zależnym.

W ciekawym badaniu przeprowadzonym we Vienna Chamber wykazano po podaniu $5 \mathrm{mg}$ desloratadyny redukcję dolegliwości o $25 \%$ już w 160 . min [20]. Co więcej, desloratadyna stosowana w zalecanej dawce $5 \mathrm{mg}$ znamiennie istotnie zmniejszyła zużycie $\beta$-mimetyków i nasilenie objawów towarzyszących astmie [21]. Większość leków z tej grupy, w tym desloratadyna i lewocetyryzyna, nie wywołuje powikłań me- tabolicznych, nie blokuje układu cholinergicznego ani adrenergicznego, a co więcej - nie wpływa na funkcjonowanie kanałów jonowych w sercu. Dobry wskaźnik monitorowania stężenia leku we krwi (czas wchłaniania leku 0,8-3 h i działania do 24 h) sprawia, że leki przeciwhistaminowe II generacji to szczególna grupa w terapii chorób alergicznych $[10,11]$ (tab. 2).

Desloratadyna skutecznie hamuje: syntezę IL-4 i IL-3 oraz IgE-zależne i IgE-niezależne uwalnianie tryptazy, leukotrienu $\mathrm{C} 4$ i prostaglandyny $\mathrm{D}_{2}$ z komórek tucznych i bazofilów, a także ekspresję selektyny $\mathrm{P}$ na powierzchni komórek śródbłonka [22]. Co więcej, hamuje w warunkach in vitro ekspresję cząsteczki CD107a, a w badaniach in vivo jest kilkadziesiąt razy silniejsza względem loratadyny [23-25]. Nie wywiera negatywnego działania sedatywnego, arytmogennego, nie ma wpływu na łaknienie, sen i zachowanie równowagi ze względu na brak przenikania do ośrodkowego układu nerwowego. Nie wchodzi w interakcje $\mathrm{z}$ innymi lekami, a działania niepożądane występują wyłącznie w grupie pacjentów z osobniczą wrażliwością na składniki leku [3].

W przypadku ANN dobry efekt terapeutyczny uzyskuje się w leczeniu skojarzonym i najczęściej łączy się opisywaną grupę leków z lekami obkurczającymi naczynia błony śluzowej jamy nosa. Wykazano, że u pacjentów, u których rozpoznaje się alergiczny nieżyt nosa o charakterze przewlekłym, stosowanie łącznie leku przeciwhistaminowego II generacji (desloratadyny lub lewocetyryzyny) i przeciwleukotrienowego zwiększa skuteczność terapeutyczną vs monoterapia [26]. $\mathrm{Z}$ kolei w celu utrzymania dobrej kontroli choroby w sytuacji jej braku należy włączyć dnGKS, np. mometazon $200 \mu \mathrm{g}$ raz dziennie z lewocetyryzyną stosowaną doustnie w dawce $5 \mathrm{mg} / 24 \mathrm{~h}$ [27]. Badania porównawcze względem poszczególnych postaci leków przeciwhistaminowych II generacji wykazują znamiennie istotną przewagę jednych leków nad innymi. Przykładem jest badanie randomizowane z podwójnie ślepą próbą oceniającą redukcję dolegliwości nosowych w przebiegu ANN mierzone skalą tTTS. Okazało się, że lepszy efekt terapeutyczny wykazano w leczeniu desloratadyną $5 \mathrm{mg}$ względem lewocetyryzyny $5 \mathrm{mg}$. Uzyskano istotną poprawę kliniczną dzięki stosowaniu

Tabela 2. Właściwości farmakodynamiczne i farmakokinetyczne desloratadyny i lewocetyryzyny w leczeniu alergicznego nieżytu nosa (na podstawie $[10,11]$ ).

\begin{tabular}{|c|c|c|c|c|c|}
\hline $\mathrm{C}_{\max }(\mu \mathrm{g} / \mathrm{ml})$ & $\mathrm{T}_{\max }(\mathrm{h})$ & Wiązanie przez białka osocza & $\mathrm{T}_{1 / 2}(\mathrm{~h})$ & Metabolizm & Wydalanie \\
\hline \multicolumn{6}{|c|}{ Desloratadyna } \\
\hline 0,3 & 3 & $83-87 \%$ & 27 & nie hamuje CYP3A4 in vivo ani CYP2D6 in vitro & z moczem $41 \%$ i kałem 47\% \\
\hline \multicolumn{6}{|c|}{ Lewocetyryzyna } \\
\hline 0,9 & 1 & $90 \%$ & $7,9 \pm 1,9$ & $14 \%$ dawki w organizmie & z moczem 85,4\%, z kałem $12,9 \%$ \\
\hline
\end{tabular}


desloratadyny $11,3 \pm 2,5$ vs lewocetyryzyna $7,9 \pm 2,4$; $\mathrm{p}<0,05$ [4]. Ciprandi i wsp. w badaniu randomizowanym z podwójnie ślepą próbą wykazali, że skuteczność obydwu leków była na podobnym poziomie statystycznym [28].

\section{Przypadek 2.}

26-letni mężczyzna zgłosił się do poradni alergologicznej z powodu występujących od 3 lat objawów pod postacią kichania, wodnistego kataru, blokady nosa i swędzenia oczu. Powyższe symptomy zawsze pojawiają się w kwietniu i trwają ok. 2 tygodni. Poza tym okresem u chorego nie występowały objawy nieżytu nosa. Dotychczas ogólnie był zdrowy, negował kaszel i duszność. Matkę pacjenta od wielu lat leczono z powodu alergicznego nieżytu nosa i astmy. We wczesnym dzieciństwie u chorego rozpoznano alergię na białka mleka krowiego i do 3. r.ż. stosowano u niego dietę bezmleczną; po 3. r.ż. symptomy się wycofały i pojawiła się tolerancja produktów mlecznych. Pacjent jest aktywny zawodowo, uprawia też kolarstwo. W poradni wykonano punktowe testy skórne, które były dodatnie jedynie w przypadku alergenów brzozy. Opierając się na zaleceniach i kwalifikacji nieżytów nosa dokumentu ARIA, rozpoznano okresowy ANN o łagodnym stopniu nasilenia w przebiegu uczulenia na pyłek brzozy. Zastosowano leczenie sezonowe doustnym lekiem przeciwhistaminowym II generacji - lewocetyryzyną $5 \mathrm{mg}$ raz dziennie 1 tabletka, po czym uzyskano znaczną poprawę i redukcję objawów ANN. Podczas wizyty kontrolnej chory zgłosił jednak uczucie senności po przyjęciu leku, co skutkowało zmniejszeniem wydolności w wykonywaniu pracy zawodowej. Podjęto decyzję o zmianie leku na inny preparat, również lek przeciwhistaminowy II generacji - desloratadynę $5 \mathrm{mg}$. Lek był bardzo dobrze tolerowany, redukował symptomy ANN oraz nie powodował uczucia senności i zmęczenia. Różnica w tolerancji preparatów prawdopodobnie wynikała $\mathrm{z}$ indywidualnej tolerancji leków przeciwhistaminowych o podobnym mechanizmie działania, lecz odmiennej budowie chemicznej.

\section{Przypadek 3.}

6-letnia dziewczynka została przyjęta do poradni alergologicznej $\mathrm{z}$ powodu znacznie nasilonych odczynów skórnych (wyraźny rumień, bąbel i świąd) po ugryzieniu przez komary. Po znacznej ekspozycji na ugryzienia wystąpił również epizod pokrzywki uogólnionej. Dziewczynka dotychczas pozostawała zdrowa. Wywiad atopowy osobniczy i rodzinny był ujemny. Lekarz rodzinny zastosował profilaktycznie desloratadynę $\mathrm{w}$ dawce $2,5 \mathrm{mg}$ raz dziennie $\mathrm{w}$ postaci tabletek, jednak nie uzyskano pełnej kontroli objawów. Wykonano badanie sIgE - panel wziewny, pokarmowy oraz na jady owadów. Wyniki panelu wziewnego i pokarmowego były ujemne, stwierdzono zaś dodatnie wyniki sIgE w klasie III na jad komara. Zastosowano lewocetyryzynę $\mathrm{w}$ postaci tabletek w dawce $5 \mathrm{mg}$ raz dziennie, po czym uzyskano znaczną redukcję symptomów, oraz zalecono regularne stosowanie repelentów w okresie ekspozycji na ugryzienia komarów. W tym przypadku preparat lewocetyryzyny, zarejestrowany do stosowania u dzieci w dawce $5 \mathrm{mg}$ od 6. r.ż., okazał się skuteczniejszy od desloratadyny, zarejestrowanej do stosowania u dzieci w tym wieku w dawce $2,5 \mathrm{mg}$.

\section{Komentarz}

Lewocetyryzyna wykazuje prawie dwukrotnie wyższe powinowactwo do receptora $\mathrm{H}_{1}$ vs cetyryzyna $\mathrm{i}$ istotnie wyższe $\mathrm{w}$ stosunku do desloratadyny, co się przekłada na dłuższy czas działania lewocetyryzyny [4]. Efektem tego może być m.in. statystycznie znamiennie dłuży czas działania lewocetyryzyny niż cetyryzyny w bąblu indukowanym histaminą [29]. W badaniu oceniającym czas działania lewocetyryzyny, która istotnie hamowała powstanie bąbla i rumienia, najsilniejsze działanie obserwowano $\mathrm{w}$ ciągu pierwszych $12 \mathrm{~h}$ i utrzymywało się ono na istotnym poziomie statystycznym $(p<0,001)$ w porównaniu z placebo i desloratadyną. Na poziomie komórkowym $w$ badaniach klinicznych in vitro udowodniono, że lewocetyryzyna hamuje indukowaną przez eotaksynę przezśródbłonkową migrację eozynofilów przez komórki skóry i pluc. Co więcej, w ocenie farmakodynamicznej lewocetyryzyna hamuje także uwalnianie cząstki adhezyjnej komórek naczyniowych (VCAM-1, vascular cell adhesion molecule 1), zmianę przepuszczalności naczyń i zmniejszenie napływu eozynofilów [30].

\section{Podsumowanie}

Terapia chorób alergicznych odgrywa kluczową rolę w dobrej kontroli choroby. Leki przeciwhistaminowe II generacji i dnGKS spełniają kryteria leków o wysokim stopniu skuteczności i bezpiecznym profilu działania.

\section{Piśmiennictwo}

1. Samolinski B, Raciborski F, Lipiec A et al. Epidemiologia Chorób Alergicznych w Polsce (ECAP). Alergol Pol. 2014; 1(1): 10-8.

2. Raciborski F, Kłak A, Czarnecka-Operacz M et al. Epidemiology of urticaria in Poland - nationally representative survey 
results. Postepy Dermatol Alergol. 2018; 35(1): 67-73. http:// doi.org/10.5114/ada.2018.73165.

3. Brożek JL, Bousquet J, Baena-Cagnani CE et al. Allergic Rhinitis and its Impact on Asthma (ARIA) guidelines: 2010 Revision. J Allergy Clin Immunol. 2010; 126: 466-76.

4. Samoliński B, Arcimowicz M (ed). Polskie Standardy Leczenia Nieżytów Nosa (PoSLeNN). Alergol Pol - Polish J Alergol. 2013; S1: 1-167.

5. Raciborski F, Bousquet J, Namystowski A et al. Correction to: Dissociating polysensitization and multimorbidity in children and adults from a Polish general population cohort. Clin Transl Allergy. 2019; 9: 23. http://doi.org/10.1186/s13601019-0263-x

6. Akkas H, Aydin E, Türkoglu Babakurban $S$ et al. Effect of mometasone fu roate nasal spray on the DNA of nasal mucosal cells. Turk J Med Sci. 2018; 48(2): 339-45.

7. Schafer T, Schnoor M, Wagenmann M et al. Therapeutic Index (TIX) for intranasal corticosteroids in the treatment of allergic rhinitis. Rhinology. 2011; 49(3): 272-80.

8. Ciprandi $G$, Varricchio A. The relevance of the Mometasone furoate nasal spray in clinical practice. J Biol Regul Homeost Agents. 2018; 32(4): 1051-4.

9. Eztom (mometazon [furoinian mometazonu]) - aerozol do nosa, zawiesina. www.mp.pl (access: 15.10.2021).

10. http://leki.urpl.gov.pl/files/26_Hitaxa_oral_sol.pdf (access: 15.10.2021).

11. http://leki.urpl.gov.pl/files/Contrahist_tablets_PL.pdf (access: 15.10.2021).

12. Sadowska-Woda I, Bieszczad-Bedrejczuk E. Spektrum działania farmakologicznego desloratadyny. Alerg Astma Immunol. 2010; 15(4): 189-96.

13. http:/lec.europa.eu. Aneks $i$ charakterystyka produktu leczniczego Desloratadine ratiopharm $5 \mathrm{mg}$, tabletki powlekane.

14. Rygalski M, Zawisza E. Atrybuty nowoczesnego leku przeciwhistaminowe. Lek w Polsce. 2015; 25(3): 20-5.

15. Camelo-Nunes IC. New antihistamines: a critical view. J Pediatr. 2006; 82(5 suppl): 173-80.

16. Passali D, Spinosi MC, Crisanti A et al. Mometasone furoate nasal spray: a systematic review. Multidiscip Respir Med. 2016; 11: 18. http://doi.org/10.1186/s40248-016-0054-3.

17. Kim DH, Kim BY, Shin JH et al. Intranasal azelastine and mometasone exhibit a synergistic effect an a murine model of allergic rhinitis. Am J Otolaryngol. 2017; 38(2): 198-203.

18. Staevska M, Popov TA, Kralimarkova T et al. The effectiveness of levocetirizine and desloratadine in up to 4 times conventional doses in difficult-to-treat urticarial. J. Allergy Clin Immunol. 2010; 125(3): 676-82.

19. Kaplan AP. Treatment of chronic spontaneous urticaria. Allergy Asthma Immunol Res. 2012; 4: 326-31.

20. Horak F, Stubner UP, Zieglmayer R et al. Onset and duration of action of desloratadine after controlled pollen challenges in patients with seasonal allergic rhinitis. Allergy. 2000; 279, abstract.

21. Marciniak-Bocheńska M, Kupczyk M, Bogacka E et al. Wptyw desloratadyny $w$ dawce $5 \mathrm{mg}$ na dobę na częstość stosowania B2 agonistów oraz objawy nieżytu nosa i astmy oskrzelowej u pacjentów z sezonowym alergicznym nieżytem błony śluzowej jamy nosa. Pneumonol Alergol Pol. 2004; 72: 296-307.

22. Reinartz SM, Overbeek SE, Kleinjan A et al. Desloratadine reduces systemic allergic inflammation following nasal provocation in allergic rhinitis and asthma patients. Allergy. 2005; 60(10): 1301-7.

23. Narbutt J. Leki przeciwhistaminowe II generacji w praktyce codziennej. Pediatr Med Rodz. 2012; 8(4): 351-9.

24. Panek M, Pietras T, Kuna P. Leki antyhistaminowe - kiedy $i$ jak stosować $w$ chorobach alergicznych. Terapia. 2014; 3(1): 23-9.

25. Ciebiada M, Ciebiada-Górska M, Górski P. Desloratadyna $w$ leczeniu całorocznego alergicznego nieżytu nosa - wieloośrodkowe badanie w Polsce. Alerg Astma Immunol. 2002; 8(2): 101-5.

26. Wei $C$. The efficacy and safety of H1-antihistamine versus Montelukast for allergic rhinitis: a systematic review and meta-analysis. Biomed Pharmacother. 2016; 83: 989-97.

27. Tatar EC, Surenoglu UA, Ozdek A et al. The effect of combined medical treatment on quality of life in persistent allergic rhinitis. Indian J Otolaryngol Head Neck Surg. 2013; 65(Suppl 2): 333-7.

28. Ciprandi G, Cirillo I, Vizzaccaro A et al. Desloratadine and levocetirizine improve nasal symptoms, airflow, and allergic inflammation in patients with perennial allergic rhinitis: a pilot study. Int Immunopharmacol. 2005; 5(13-14): 1800-8.

29. O'Donnel BF, Lawor F, Simpson J et al. The impact of chronic urticaria on the quality of life. Br J Dermatol. 1997; 136(2): 197-201.

30. http://leki.urpl.gov.pl/files/Contrahist_tablets_PL.pdf (access: 15.10.2021)

ORCID

E. Krzych-Fałta - ID - http://orcid.org/0000-0002-9857-7136

0. Wojas - ID - http://orcid.org/0000-0003-1653-9388

B. Samoliński - ID - http://orcid.org/0000-0002-4043-7747

Wkład autorów/Authors' contributions:

B. Samoliński: 20\%; 0. Wojas: 30\%; E. Krzych-Fałta: 50\%.

Konflikt interesów/Conflict of interests:

Nie występuje.

Finansowanie/Financial support:

Nie występuje.

Etyka/Ethics:

Treści przedstawione w artykule są zgodne z zasadami Deklaracji Helsińskiej, dyrektywami EU oraz ujednoliconymi wymaganiami dla czasopism biomedycznych.

Copyright: (C) Medical Education sp. z 0.0. This is an Open Access article distributed under the terms of the Attribution-NonCommercial 4.0 International (CC BY-NC 4.0). License (https://creativecommons.org/licenses/by-nc/4.0/), allowing third parties to copy and redistribute the material in any medium or format and to remix, transform, and build upon the material, provided the original work is properly cited and states its license. 
Adres do korespondencji

dr hab. n. o zdr. Edyta Krzych-Falta

Zakład Alergologii i Immunologii Klinicznej,

Uniwersyteckie Centrum Kliniczne,

Warszawski Uniwersytet Medyczny

02-097 Warszawa, ul. Banacha 1A

e-mail: edyta.krzych-falta@wum.edu.pl https://www.journalsmededu.pl/index.php/alergoprofil: 26.04.2023; 11:31,51 